\title{
"Death is a disease": Cryopreservation, neoliberalism, and temporal commodification in the U.S.
}

\author{
Taylor R. Genovese \\ School for the Future of Innovation in Society, Arizona State University, P.O. Box 875603, Tempe, AZ 85287-5603, USA
}

\section{Introduction}

In Darren Aronofsky's 2006 film The Fountain [39], the protagonist, Tommy-played by Hugh Jackman-proclaims to a laboratory colleague after his wife dies from brain cancer, "Death is a disease. It's like any other. And there's a cure... and I will find it." While this re-framing of death as a medical diagnosis to overcome and in need of a "cure" may seem facetious-or perhaps, to some, horrifying-humankind's array of religions have spent at least a section of their scriptures trying to explain away death's finality [32]. Until quite recently in human history, death has been less articulated to materialistic notions of the physical but instead has been coupled with discussions about the spiritual.

Somewhat situated at the crossroads of the physical and the spiritual is the transhumanist movement. The transhumanists are a meliorist movement that hope to enhance human intellect and physiology by applying scientific and technological advances to "enhance" individual human bodies. The movement can be traced back to Nikolai Fedorovich Fedorov's "cosmist" movement at the turn of the 20th century whose goals consisted of: establishing universal immortality for human beings, resurrecting the dead, engineering the human body for spaceflight, and freedom of movement throughout the cosmos [41]. One modern enactment of the transhumanist philosophy is that of cryopreservation, or freezing one's body after death with the hope of being reanimated in the future.

In this article, I will be focusing specifically on cryopreservation and two of the American biotechnomedical tenets introduced by Robbie Davis-Floyd and Gloria St. John [5] in their technocratic model of medicine: the "body as machine" and "death as defeat." These axioms are embraced by both the biotechnomedical establishment as well as the cryopreservation communities when they discuss the future of humankind. In particular, I will be focusing on the political economy of cryopreservation as an embodiment of American neoliberalism-as well as a Durkheimian death ritual—in the twenty-first century. Finally, I will theorize on a future populated by human beings from "the past" and the implications and consequences that may be caused by contemporary humans experiencing a temporal shift from traveling in deep time vis-à-vis cryopreservation.

\section{Cryonic assemblages}

Cryopreservation is the practice of accepting a body after medical "death" and cooling a patient's body to $-196^{\circ} \mathrm{C}$ in order to "vitrify" them: to replace over half of the water in the human body with chemicals that prevent cell damage caused by ice crystals, and freezing the body to a stable, ice-free state. After vitrification, the patient ${ }^{1}$ is stored within vacuum-insulated dewars stabilized at a temperature of $-196^{\circ} \mathrm{C}$ with liquid nitrogen in order to await a future in which biomedical technologies may be able to reanimate them [1]. The idea behind cryopreservation-like many modern technological advancements-was first introduced in science fiction [31]. Robert C.W Ettinger's [9] book The Prospect of Immortality calls for humanity to enter "freezer programs" immediately after medical death in the hopes that one day scientific advancements would be able to restore life or even grant the patient with immortality.

While this may sound like pure science fiction, many cryopreservation advocates claim that the practice is scientifically realizable, even if it cannot be theoretically or technically validated by current scientific methods. However, that is not to say that contemporary medical studies are not experimenting with techniques relevant to cryopreservation. Recent experiments have shown that induced hypothermia after cardiac arrest resuscitation has prevented-or slowed-neurological, renal, and other issues related to the cessation of blood flow from the heart [2,27]. Additionally, there have been cases discussed by Abou Farman [10; 742] of patients resuscitated with little to no cerebral impairment after suffering "accidental hypothermia," such as falling into frozen rivers, being buried under avalanches, etc. This research has excited cryonic and cryopreservation advocates and proves, in some of their minds at least, the feasibility of cryopreservation. Furthermore, many cryopreservation advocates assert that the criterion for death will continue to shift as biotechnomedicine continues to advance, and a patient placed immediately into cryopreservation after they're pronounced "legally dead" by a doctor in 2018 may not be considered dead at all by a doctor in 2118-but rather, they

\footnotetext{
E-mail address: taylor.genovese@asu.edu.

${ }^{1}$ A quick note on this lexical choice: I use the word patient here because this is how cryopreservation institutions refer to those who have elected to be cryopreserved. Many within the current medical profession would view cryopreserved bodies as human remains.
} 
will be seen as a patient in suspended animation awaiting revival.

Once again, this may not be as fantastical as it sounds if one compares it to the amount of flexibility that existed in when a patient was considered "dead" prior to the Uniform Determination of Death Act. This model state law was designed to standardize when a patient was considered "legally dead," and as of 2018 it has been adopted by 38 states, including the District of Columbia [7]. However, cryopreservation advocates make a distinction between a "legally dead" patient who has lost brain function and "information theoretical death"- that is, according to the cryopreservationists, the point when the patient's personality, memories, hopes, dreams can no longer be salvaged-which advocates claim is prevented by immediately cryopreserving a patient who has been declared dead by a doctor [34]. Therefore, death becomes socially constructed, as well as a process, rather than a moment [10]. This also illustrates the fact that terms like "consciousness" and "death" are part of a contested terrain that are shaped more by the political side of biopolitics than the medical side [30]. Through this shift, cryopreservation advocates play out a narrative utilizing current biomedical terminology in order to bound their reality of when "actual" death occurs as being after "information theoretical death" [31].

American biotechnomedicine's relationship with death as a social and legal process has also been quite fluid. Most recently, the phenomena of so-called "beating heart cadavers" has been sensationalized in Dick Teresi's [38] book on the topic. He highlights the fluctuating moments of death within medicine as sliding between heart-death and brain-death. One doctor interviewed by Teresi $[38 ; 145]$ refers to braindead patients who are kept alive with ventilators as "pretty dead." That is, their lungs are still breathing, their hearts are still beating, but this medical decision is only pursued so that blood can be circulated throughout the body in order to keep the organs viable for harvesting. In contrast, a person whose heart has stopped beating is considered "dead-dead," and if this happens to a patient who is already "pretty dead," medical staff will still attempt to "resuscitate," despite the patient existing within this liminal landscape of death [38]. It is important to stress that this perspective is explicitly Americanist; for example, Japanese medical professionals and public have long been critical of brain-death equating human-death. In fact, Japanese law allows for citizens to choose for themselves which death will be legally recognized for them: heart-death or brain-death [22]. This critical stance toward brain-death has begun to take hold within the U.S., especially as suspicious symptoms-such as racing heartbeats during organ harvesting surgeries on the "pretty dead"-have been reported by transplant surgeons [38]. Furthermore, a study conducted at Stony Brook University found that of the 2060 survivors of cardiac arrest interviewed, 46\% reported "post-resuscitation memories" and $2 \%$ reported full awareness after medical death [26]. This leads Teresi $[38 ; 150]$ to pose the gruesome question: "What does a 'pretty dead' patient experience during a three- to five-hour harvest sans anesthetic?"

The Alcor Life Extension Foundation ${ }^{2}$ subscribes to this liminal death model but reaches further than the current medical establishment: "Cryonics is not a belief that the dead can be revived. Cryonics is a belief that no one is really dead until the information content of the brain is lost, and that low temperatures can prevent this loss" [4]. The cryopreservation institution's entire scientific and business model is dependent on this hope. In a way, cryopreservation is a fight against entropy; a battle against the heat death of the universe within the human microcosm.

The compartmentalization of death, life, consciousness, and what

\footnotetext{
${ }^{2}$ Alcor is a Scottsdale, Arizona based NGO that researches, advocates, and performs cryonic services. As of January 31, 2018 they have 1149 members (those who have elected for cryopreservation), 292 associate members (those who have not made cryopreservation plans but wish to financially support Alcor's mission), and 155 patients who are cryopreserved.

${ }^{3}$ This turn of phrase is owed to Martin Pfeiffer, who elegantly expressed this to me during our conversations on the topic.
}

exactly it means to be a human is drawn from a radical reimagining of the mind-body separation argued by Descartes, Bacon, Hobbes, and other Western philosophers. This Cartesian dualism was initially inspired by, and is now fused with, the hegemonic institutions of scientific materialism [33]. This scientific hegemony is paired with the "supervaluation of science and technology," [5; 34] which elevates biotechnomedicine (including cryonics) to a revered status within our technocratic capitalist society-even if cryopreservation may evoke the same smug smirk today that was given to those advocating airplanes in the early twentieth century.

In fact, I would challenge scholars studying cryopreservation to take members of cryopreservation organizations at their word, rather than having to first laugh off the implausibility of it all-much like how Puar [29], in her book Terrorist Assemblages, argues against the tendency that before one talks about suicide bombers, one tends to first feel the need to morally condemn them in order to alleviate risk. It is unclear whether these actions are taken in order to perform as the "rational academic" for colleagues and the academy at large, but it levies an amount of unethical disrespect toward research participants. Critiquing cryopreservation is important-and I will be doing a fair amount of that starting with the next paragraph-but a critical position holds far more weight when one begins with a relativistic stance. All research on matters concerning the future contain a high level of speculative imagination, and this foundation of uncertainty is shared between academics and cryopreservation advocates alike.

That said, it can be troubling when modern biotechnoscience supports the scientific materialist compartmentalization of human beings-the Cartesian breaking down of people into "body-machine" objects [5; 23]. In Donna Haraway's [15; 301] recent engagements with her construction of the cyborg, she states that she no longer views cyborgs as hybrids, but instead as "imploded entities, dense material semiotic 'things'-articulated string figures of ontologically heterogeneous, historically situated, materially rich, virally proliferating relating of particular sorts." This multifaceted approach to what we consider human-and ways in which cryopreservation interacts with the human and the nonhuman-is what I am calling the cryonic assemblage. Puar [29; 217], in writing about suicide bombers, proposes a definition that also works within the cryonic assemblage: "Assemblage here points to the inability to clearly delineate a temporal, spatial, energetic, or molecular distinction between a discrete biological body and technology..." When the human body-or parts of the human body-are drained, vitrified, and encased within techno-dewars that monitor and adjust temperatures autonomously, the cryonic assemblage seems to breach the most popular biological ontology of what it means to be human.

The cryonic assemblage takes seriously Rabinow and Rose's [30] discussion of the possibility for a new regime of biopower to take shape centered around novel configurations of knowledge, power, and subjectivity within biotechnomedical fields. My proposed cryonic assemblage includes a plea to think outside of the traditional Foucauldian configurations of biopower and to reflect on how contemporary cryopreservation advocates and organizations might be able to colonize and transform pre-existing apparatuses-such as the pharmaceutical industry, government investment, patient and lobbying groups, and biotechnomedical companies-in ways that may fundamentally change the way we think about health and medicine in the United States. These structural "mutations," as Rabinow and Rose [30; 214] call them, will most likely be minute and diffuse, making it much harder to spot their effects in the short term, if they make a difference at all. However, from the perspective of the future, these new regimes of biopower have the potential to completely reconfigure relations of knowledge, power, and expertise surrounding life, death, and time itself and, if nothing else, that possibility should be taken seriously as a subject of scholarly inquiry [30]. 


\section{Cryonics as embodied neoliberalism \& time as commodity}

Emile Durkheim [8] was an influential social scientist that systemically and academically engaged with the meanings behind death rituals in his The Elementary Forms of the Religious Life. Durkheim claimed that mortuary rites served primarily to promote social cohesion and to reaffirm common societal values. While this simplification ignores many of the nuances that exist within humanity's use of symbol, myth, and ritual, there remains an important kernel of truth animating his observations. Kiong and Schiller [18; 5] echo Durkheim in their assertion that "death rituals must... be viewed as culturally heightened activities; they conflate, refract, and highlight a people's most important values." Cryopreservation has largely been an American practice ever since Dr. James Benford became the first person to be cryopreserved in 1967..$^{4}$ There are two main cryopreservation companies-Cryonics Institute in Detroit, Michigan and the Alcor Life Extension Foundation in Scottsdale, Arizona-as well as a third organization, Suspended Animation, based in Florida, that only handles the vitrification process [10]. So, if we view the practice of cryopreservation as an American community's Durkheimian death ritual, what sort of values would we see rise to the surface?

Tiffany Romain [31; 205] claims that the "imaginaries that permeate cryonics are not simply of radically extended lifespans, but are technophilic, biological materialist, American, atheistic, [right-] libertarian, and masculine in nature." Farman [10] reports observing similarly gendered and technoutopian ideological imaginaries during his experience working with cryopreservation advocates. The cryopreservation community may be illuminating essential American values, as these tenets are also present within the American neoliberal imaginary. ${ }^{5}$ Capitalism is predicated on the assumption that people will frame their identity through their possessions, based on a fear of material scarcity and loss, in an extension of what Marx [21] called commodity fetishism. Cryopreservation plays into this fear of loss by offering not only an insurance policy against the ultimate loss (one's own life), but also possibilities of additional material and/or wealth accumulation in the future [31].

Michel Foucault's analysis of biopower continues to lay the foundation for how cryopreservation can be articulated as an embodiment of neoliberalism. Foucault's theorizations on biopower offer a twopronged commentary that can be helpful when thought of as a precursor to neoliberalism, particularly as it relates to the overall cryopreservation project. The first is that of the distributed disciplining of bodies and subjectivities and the way that discipline can pervasively affect space(s) and movement(s) inhabited by those bodies and subjectivities [11,12]. The second is that of biopolitical power, or biopolitics, which looks specifically at governmentality and populations, rather than the individualized subject/bodies; of particular importance to cryopreservation, Foucault $[13,14]$ looks at the ways that biopolitical technologies intrude in the life cycles of populations and begin to inculcate certain values, such as the embodied market relations of neoliberalism.

Cryopreservation, then, becomes the apex of neoliberal thinking. The neoliberal promise is that one has the "individual liberty" to save for retirement, for medical emergencies, for education, a car, a house.

\footnotetext{
${ }^{4}$ For 38 years, cryopreservation was only practiced within the United States. However, in 2005, КриоРус (KryoRus) publically opened in Moscow. On their website, KryoRus claims to have successfully cryopreserved 56 people and 22 pets [19].

${ }^{5}$ It is here that I would like to quickly gloss the term "neoliberal(ism)," since the word has, in recent years, been used rather indiscriminately as a blanket pejorative by a wide range of scholars. Broadly, neoliberalism is a belief that human well-being can best advance by extending competitive market relations into every aspect of human life-including the economy, politics, and society; beginning in the 1970s, this belief has been hegemonically propagated by inculcating certain market-based values and social practices into every part of American life $[16,35,36]$. This gives the effect that neoliberalism is both everywhere ("This is the way it has always been!") and nowhere ("You radicals are just making things up!").
}

The inescapable specter of death, however, has always been unconquerable by capital—no matter how hard one has pulled themselves up by their bootstraps. Cryopreservation is presented as a solution that resolves the American fear of death while feeding into the mythos of neoliberalism: that the individual paired with the free-market is an undisputed, powerful cure-all for society's problems. Furthermore, cryopreservation infuses neoliberalism directly into the human body; it turns the body into a special type of property that is able to be invested and banked, with a potential return of immortality in the future [31]. In fact, Farman [10] illustrates how the Uniform Anatomical Gift Act-a law passed in 1968 that allows patients to transfer their bodies to cryopreservation organizations as donations for scientific research-legally allows the body to be broken down into property, into parts, into things. Instead of the Puarian [29; 217] "body-weapon" of suicide bombers, cryopreservation opens up an embodied ontological engagement that could be described as body-capital. Cryopreservation literally commodifies the assemblages of the body and then recomposes that cryonic assemblage according to the dictates and logic of capitalism, contributing to what Kaushik Sunder Rajan [37] calls "technoscientific capitalism." Furthermore, body-capital of the cryopreserved is directly related to the medically enabled redefinition of death-as-process in the "pretty dead" status of beating heart cadavers as well as an extension of the long standing commodified body-capital markets of plasma, eggs, sperm, stem cells, etc.

The ethical issues and problems of governance that exist within the broader cryonics markets relate to issues that may arise within cryopreservation circles. In 2016, the United States military decided to extend cryonic benefits to service members, allowing them to freeze their eggs or sperm for future use [17]. This opens up potential legal conflicts arising from these new forms of subjectivity and life, not to mention the social and religious controversies that have long simmered since cryonic technologies became marketable. For example, does a child conceived from a frozen egg (or sperm) after the death of the egg (or sperm) donor deserve military death benefits from the U.S. government?

Enlightenment and modernist conceptions of expertise and experts are explicit enablers of this type of capitalist parsing of bodies and life processes. The social construction of expertise has allowed for the rise of a situation where people learn a certain set of skills that imbues them with the power to become the keepers of brains and bodies within this neoliberal capitalist system, giving them control of life and death according to their version of reality. The construction of expertise and the creation of an expert class are engrained with a certain amount of power and political capital. Experts have the ability to wield authority-a political concept-over questions of true belief without being democratically accountable to their truths $[11,40]$.

However, expertise is not a monolithic practice, it is always in a state of flux that is open to being challenged. Expertise is constantly being socialized and reproduced, mobilized through institutionalization, and naturalized through expert enactments as a body of knowledge [3]. Experts are intertwined and constructed within the Rabinow and Rose [30] triad of knowledge-power-subjectivity that mobilize and constitute links between life, truth, and value according to the multiple logics that exist within the capitalization of biotechnomedicine, as well as whether commercial enterprises are allied or autonomous from States and their spheres of ideological influence. For example, expertise about smoking risk that flow from the American Cancer Society or the Centers for Disease Control are most likely going to differ significantly from the experts employed by Philip Morris. Expertise can dialectically repel and overlap depending on how the expert implicitly configures their truth, power, and subjectivity [30].

Especially in the field of cryonics, experts may not necessarily subscribe to the traditional medical logic that their duty consists of the restoration of biological normativity that may have been lost during illness, but instead cryopreservation advocates are "engaged in the molecular re-engineering of life itself" [30; 212, emphasis Rabinow and 
Rose's]. The political economy of this knowledge production is founded on both scientist and patient hope, generated through the stakeholder's expectation that capital-s Science will accelerate linearly and usher in an optimistic future that exists within their imaginations [24]. Furthermore, hope becomes a node for biotechnomedical companies to leverage capital while reframing their future imaginaries in the present [31].

The irony of cryopreservation advocates claiming to be preserving people while simultaneously slashing a person into "de-peopled" body parts-in some cases literally, such as when a patient has elected for neuropreservation (i.e. preservation of just their head)—is not the only paradox that exists in this interpretation of embodied neoliberalism. There exists an additional and deeper contradiction in the seeming reversal of how capitalist logics view the embodied difference between the worker and the bourgeoisie. Marx [21], in his conversations on worker alienation, refers to the worker's body as being like a cog within the machine of capital-always able to be replaced and swapped out with another worker. In our present neoliberal age, capitalist philosophy has become so pervasive that it has degraded human logic to the point where even the capitalist views their own bodies through the lens of exchange value. In this way, cryopreservation can be framed as an augmentation of biopower and optimization: capitalists are extending the power of capital to expropriate value not only from the relations of production with the worker, but also with themselves [23].

Cryopreservation provides a market in which the capitalist is now able to commodify their own body after death, an apparent reversal of the Frankenstein story. In Frankenstein, Mary Shelley writes of an elite anatomist who constructs a monster literally from worker's bodies; this collection of proletarian parts awakens-seemingly gaining a class consciousness and literally breaking free from its chains-and attacks the capitalist class. In our neoliberal present, the capitalist has become the monster, with the workers acting as Dr. Frankenstein, deconstructing and banking the bodies of the rich who utilize a warped capitalist logic of investing one's sense of self and ideology for an unknown deep future.

The neoliberal narrative espoused by cryopreservation institutions and their advocates reinforces the mythology that capitalism is some kind of eternal force. In fact, these cryopreservation institutions are using time as a commodity, perpetuating the idea that everything-even time itself-can and will be commodified [31]. Governments (or the lack thereof) in the future may decide it is unethical to reanimate human beings from the past and the contracts that patients hold with cryopreservation companies may become null and void. Or perhaps legal contracts themselves will be a curiosity, a relic of the past, especially if corporatism and capitalism have been eradicated [34]. On the flip side, if our future descends into despotism, who is to say that patients will not be used as slaves, whose bodies are technically owned by the cryopreservation institutions themselves?

Many cryopreservation advocates do not seem to critically analyze what it means to be awakened in the deep future, beyond their own ideologically driven preconceptions about a temporally disconnected life. In Guy Debord's [6] The Society of the Spectacle, he introduces a concept called "spectacular time." In Thesis 152, he writes that "capitalism has begun selling 'fully equipped' blocks of time, each of which is a complete commodity combining a variety of other commodities" [6; 111]. Capital demands time of the worker-what Marx calls labortime-and this, in turn, becomes a measure of value. However, Marx's theory of value being grounded in temporal finitude is only implicit, coming out only occasionally, such as in the "voice of the worker" section of "The Limits of the Working Day" in Capital 1: "apart from natural deterioration through age etc., I must be able to work tomorrow with the same normal amount of strength, health and freshness as today" [21; 343]. Debord [6; 114] says this relationship between the capitalist and the worker is the "violent expropriation of their time."

Furthermore, Debord says that the "American way of death" depends solely on "how much of the appearance of life can be maintained in the individual's encounter with death" [6; 115, emphasis Debord's]. What appears more like life within the American conceptions of death than cryonic slumber, in which one's death is not finite, but merely a liminal stage before eternal life in the deep future? Debord continues by saying that due to advertising campaigns, Americans feel that "it is simply forbidden to get old," which plays into what he calls the "capital of youth" [6;115]. Articulating this framework to cryonic imaginaries and motivations allows us to account for the right-libertarian vision of the future-that is, capital is natural and inescapable and that technology is always progressive and for "good"-while also considering the American fear of death and the obsession to remain youthful.

I propose that revived patients would be regarded as temporal refugees. If not labeled as such by those in the future, they may begin to utilize that label for themselves. These temporal refugees would be entering a time that harbors no sense of belonging, no language familiarity, no kinship, and no relation to the culture of time that the refugee was used to. After all, if governments and people within our own time cannot accepted mass migration across our planet freely and without malice, how would humans in the future feel about those who are also temporally disconnected? Furthermore, would the ontological assumptions about what is considered a "human being" still be uniform and recognizable in the future to a cryopreservation patient from the twenty-first century?

\section{Temporal oddities}

During a conversation with anthropologist David Valentine, we discussed the phenomena of futurist philosophers and companies always announcing that humanity is only a few short decades away from a massive breakthrough in technology - whether that be the singularity, the spread of humanity beyond our planet, the discovery of cold fusion techniques, contact with intelligent extraterrestrial life, etc. He labeled this phenomena "uneven temporality" (Valentine, personal communication, October 13, 2016). Futurist discourse has often been fragmented and possessed a quality of hopeful unevenness. Perhaps that is why it is latched onto so quickly and easily within the lay technofuturist imaginary. Within the Enlightenment, meliorist tradition, one always wants to hope and believe that they are living in a time that is on the leading edge of innovation, not stuck in a quagmire era labeled statusquo or degenerative. I find it interesting that these futurist imaginaries are vaporous-a mirage, or a rainbow-they are always fixed in the distance. And when one arrives in the time in which apparent innovations are supposed to exist, scientific promises continue to remain in the distance, just over that next hill.

But these promises are more than idle words; they are intertwined with the neoliberal project. The integration of market values into the imaginaries of technoutopic innovation ask us to focus on an implied glorious future while insinuating that the suffering many of us are experiencing in the present should be bracketed for the sake of that timeto-come [28]. However, the sad reality is that many continue to suffer while stumbling forward on the neoliberal treadmill, arms outstretched toward the phantasm of a better and brighter future that never arrives. This stalemate also effects cryopreservation advocates themselves, some of whom forgo having children, buying non-functional furniture or art, and spending money on anything they may consider frivolous; as Romain [31; 208] points out, this kind of contemporary worldly asceticism is one of "work and preparation" for a promised sunnier future that will reward their sacrifice and devotion. Furthermore, many cryopreservation advocates will take out insurance policies, naming the cryopreservation company as the beneficiary, in order to make cryopreservation affordable [31]. Not only does this open up the possibility for corruption, it is a further act of piety to the cryopreservation project through relinquishment of individual agency to the cause.

To conclude, since I began this article with a film reference, I feel I should end it with one as well. In the Coen Brothers' film $O$ Brother, Where Art Thou? [25], George Clooney's character-Ulysses Everett 
McGill—berates a shop clerk who says he must wait two weeks for a car part, as well as an additional two weeks for McGill's favorite pomade (he doesn't want Fop, damnit, he's a Dapper Dan man!). McGill loudly exclaims, "Well, ain't this place a geographical oddity! Two weeks from everywhere!" So I would like to tweak Valentine's label and propose the phrase temporal oddity to describe this similar acceptance by the public when it comes to the technological imaginary-always twenty years away from solving humankind's troubles! But even if these temporal oddities somehow manifest into a reality, the problems of becoming a temporal refugee remain, as imagined in the episode "The Neutral Zone" in Star Trek: The Next Generation, where one "cryonaut" was awaked 375 years in the future only to proclaim that they felt as if they were "out of time, a relic."

I should make it clear that I do not believe that hope for a brighter future is necessarily a bad concept. In fact, I would consider myself a critical utopianist. However, I caution fellow futurists not to buy into-or espouse-an un-nuanced, rose-tinted disregard for the problems we have within our contemporary reality. These problems are not going to be eliminated solely by rationally-applied technology and the passage of time; this is the great danger of utopianism. Our current reality should be treated as an analogue for our future and we must fight and defeat the enormous array of social and economic injustices that plague us, especially within the United States. Hopes, dreams, and an optimistic striving for a utopian future are good motivations, as long as one enacts them through social justice and decolonial critiques of those futures. If this is disregarded, we are doomed to a future that is as rife with inequality and misery as many of us suffer from in the present-and that is no future that I want to awaken into. If this warning is disregarded, put me in the ground with my ancestors, for perhaps humans are not quite ready for the potential positive advancement toward mutual aid, of which our species is capable.

\section{Acknowledgements}

I would like to thank Lisa Hardy who encouraged me to begin writing this piece and reviewed very early versions. I would also like to thank Sean Parson, who provided invaluable feedback and deepened my political arguments by suggesting additional readings and giving me excellent comments, revisions, and encouragement. My friend and colleague Martin Pfeiffer, as always, dropped everything he was doing to read several versions of this and provided me with his invaluable perspective. Finally, I would like to thank Nikki Stevens and Erik Fisher for reviewing and commenting on the final versions of this manuscript.

\section{Appendix A. Supplementary data}

Supplementary data related to this article can be found at http://dx. doi.org/10.1016/j.techsoc.2018.03.002.

\section{References}

[1] Alcor Procedures, Alcor life extension foundation, Accessed December 8, 2016 http://www.alcor.org/procedures.html,

[2] Stephen Bernard, Michael Buist, Orlando Monteiro, Karen Smith, Induced hypothermia using large volume, ice-cold intravenous fluid in comatose survivors of out-of-Hospital cardiac arrest: a preliminary report, Resuscitation 56 (1) (2003) 9-13.

[3] E. Summerson Carr, Enactments of expertise, Annu. Rev. Anthropol. 39 (1) (2010) 17-32, http://dx.doi.org/10.1146/annurev.anthro.012809.104948.

[4] Cryonics Myths, Alcor life extension foundation, Accessed December 8. http: www. alcor.org/cryomyths.html,

[5] Robbie Davis-Floyd, Gloria St John, From Doctor to Healer: the Transformative
Journey, Rutgers University Press, New Brunswick, 1998.

[6] Guy Debord, The Society of the Spectacle, Translated by Donald Nicholson-Smith, Zone Books, New York, (1967) 1994.

[7] Determination of Death Act, Uniform law commission, Accessed March 8. http: www. uniformlaws.org /Act.aspx?title = Determination $\% 20$ of $\% 20$ Death $\% 20$ Act,

[8] Emile Durkheim, The Elementary Forms of the Religious Life, The Free Press, New York, (1915) 1965.

[9] Robert C.W. Ettinger, The Prospect of Immortality, Doubleday \& Co., New York, (1962) 1964

[10] Abou Farman, Speculative matter: secular bodies, minds, and persons, Cult Anthropol. 28 (4) (2013) 737-759.

[11] Michel Foucault, The History of Sexuality: Vol. 1: an Introduction, Translated by Robert Hurley, Vintage Books, New York, (1978) 1990.

[12] Michel Foucault, Discipline and Punish: the Birth of the Prison, Translated by Alan Sheridan, Vintage Books, New York, (1975) 1995.

[13] Michel Foucault, Society Must Be Defended: Lectures at the Collège de France, 1975-76, Translated by David Macey Picador, New York, 2003.

[14] Michel Foucault, The Birth of Biopolitics: Lectures at the Collège de France, 1978 79, Translated by Graham Burchell Picador, New York, 2008.

[15] Donna Haraway, Awash in urine: DES and Premarin in multispecies responseability, WSQ: Wom. Stud. Q. 40 (1) (2012) 301-316.

[16] David Harvey, A Brief History of Neoliberalism, Oxford University Press, Oxford, 2005.

[17] Patricia Kime, Military's New Fertility Benefit Will Let Troops Freeze Their Sperm and Eggs, Military Times, 2016 January 29. Accessed March 12, 2018 http://www. militarytimes.com/pay-benefits/military-benefits/health-care/2016/01/29/ military-s-new-fertility-benefit-will-let-troops-freeze-their-sperm-and-eggs/.

[18] Tong Chee Kiong, Anne L. Schiller, The anthropology of death: a preliminary overview, Asian J. Soc. Sci. 21 (2) (1993) 1-9.

[19] KryoRus: The First Cryo-company in Eurasia, (КриоРус: Первая криокомпания в Евразии), KryoRus, 2018 Accessed February 13 http://kriorus.ru.

[21] Karl Marx, Capital: Volume I. Translated by Ben Fowkes, Penguin Classics, London, (1867) 1990 .

[22] Masahiro Morioka, Reconsidering brain death: a lesson from Japan's fifteen years of experience, Hastings Cent. Rep. 31 (4) (2001) 41-46.

[23] Majia Holmer Nadesan, Governmentality, Biopower, and Everyday Life, Routledge, New York, 2008

[24] Carlos Novas, Nikolas Rose, Genetic risk and the birth of the somatic individual, Econ. Soc. 29 (4) (2000) 485-513.

[25] O Brother, Where Art Thou? Directed by Joel Coen. 2000. Burbank, CA: Touchstone Pictures, 2001. DVD.

[26] Sam Parnia, Ken Spearpoint, Gabriele de Vos, Peter Fenwick, Diana Goldberg, Jie Yang, Jiawen Zhu, et al., AWARE-AWAreness during REsuscitation-a prospective study, Resuscitation 85 (12) (2014) 1799-1805, http://dx.doi.org/10. 1016/j.resuscitation.2014.09.004.

[27] Kees H. Polderman, Induced hypothermia and fever control for prevention and treatment of neurological injuries, Lancet 371 (9628) (2008) 1955-1969.

[28] Elizabeth A. Povinelli, Economies of Abandonment: Social Belonging and Endurance in Late Liberalism, Duke University Press, Durham, 2011.

[29] Jasbir K. Puar, Terrorist Assemblages: Homonationalism in Queer Times, Duke University Press, Durham, 2007.

[30] Paul Rabinow, Nikolas Rose, Biopower today, BioSocieties 1 (2) (2006) 195-217, http://dx.doi.org/10.1017/S1745855206040014.

[31] Tiffany Romain, Extreme life extension: investing in cryonics for the long, long term, Med. Anthropol. 29 (2) (2010) 194-215, http://dx.doi.org/10.1080/ 01459741003715391

[32] Antonio Sandu, The anthropology of immortality and the crisis of posthuman conscience, J. Study Relig. Ideol. 14 (40) (2015) 3-26.

[33] Nancy Scheper-Hughes, Margaret Lock, The mindful body: a prolegomenon to future work in medical anthropology, Med. Anthropol. Q. 1 (1987) 6-41.

[34] David Shaw, Cryoethics: seeking life after death, Bioethics 23 (9) (2009) 515-521.

[35] Simon Springer, Kean Birch, Julie MacLeavy, The Handbook of Neoliberalism, Routledge, New York, 2016.

[36] Nick Srnicek, Alex Williams, Inventing the Future: Postcapitalism and a World without Work, Verso, Brooklyn, 2015.

[37] Kaushik Sunder Rajan, Biocapital: the Constitution of Postgenomic Life, Duke University Press, Dunham, 2006.

[38] Dick Teresi, The Undead: Organ Harvesting, the Ice-water Test, Beating-heart Cadavers-how Medicine Is Blurring the Line between Life and Death, Vintage, New York, 2012.

[39] The Fountain Directed by Darren Aronofsky. 2006. Burbank, CA: Warner Bros. Pictures, 2007. DVD.

[40] Stephen Turner, What is the problem with experts? Soc. Stud. Sci. 31 (1) (2001) 123-149.

[41] George M. Young, The Russian Cosmists: the Esoteric Futurism of Nikolai Federov and His Followers, Oxford University Press, Oxford, 2012. 